\title{
Polymorphisms and Associations of the NRAMP-1 and iNOS Genes on Newcastle Disease and Salmonella enteritidis Resistances in SenSi-1 Agrinak Chickens
}

\author{
M. Ardiyana ${ }^{a}$, A. Gunawan ${ }^{a}$, S. Murtini ${ }^{b}$, T. Sartika ${ }^{c}$, \& C. Sumantri ${ }^{a, *}$ \\ aDepartment of Animal Production and Technology, Faculty of Animal Science, IPB University \\ (Bogor Agricultural University) \\ bepartment of Medical Microbiology, Faculty of Veterinary Medicine, IPB University \\ (Bogor Agricultural University) \\ Jalan Agatis, Kampus IPB Dramaga Bogor 16680, Indonesia \\ 'Indonesian Research Institute of Animal Production (IRIAP) \\ PO BOX 221-Bogor 16002, Indonesia \\ *Corresponding author: csumantri12@gmail.com \\ (Received 22-02-2019; Revised 06-12-2019; Accepted 27-01-2020)
}

\begin{abstract}
NRAMP-1 and iNOS genes were reported to be associated with a defense mechanism against bacteria and virus infections. This study aimed to identify NRAMP-1 and iNOS genes polymorphisms and their associations with the defense mechanisms against Salmonella enteritidis and Newcastle Disease (ND) in SenSi-1 Agrinak chicken. The present study used a total number of $\mathbf{1 7 2}$ SenSi-1 Agrinak chicken. Identifications of NRAMP-1 and iNOS genes polymorphisms were performed by PCR-RFLP method. NRAMP-1 and iNOS genotypes were associated with immunoglobulin Y (IgY) concentration, specific antibodies against S. enteritidis and ND using General Linear Model (GLM). Immunity characteristics were further grouped into high, medium, and low categories. NRAMP$1 \mid S a c I$ exon 11 and iNOS $\mid A l u$ I intron 24 in SenSi-1 Agrinak chickens were polymorphic. TC genotype has a higher immune response to infectious agents compared to TT and CC genotypes. The frequency of $\mathrm{C}$ allele was higher than the $\mathrm{T}$ allele in the concentration of immunoglobulin $\mathrm{Y}$ (IgY), antibodies titers against $S$ enteritidis and ND. The TC genotype of NRAMP-1 gene was significantly associated with ND antibody titers, and the TT genotype of iNOS was significantly associated with S. enteritidis specific antibody. NRAMP-1 and iNOS genes can be used as potential candidate genes for immune traits in SenSi-1 Agrinak chickens.
\end{abstract}

Keywords: disease resistance; iNOS gene; NRAMP-1 gene; polymorphism; SenSi-1 Agrinak chicken

\section{INTRODUCTION}

SenSi-1 Agrinak chicken breed was released from Indonesian Research Institute for Animal Production (IRIAP) to be used as a commercial meat type of local chicken in Indonesia. This breed was selected from the native breed of Sentul chicken, originating from Ciamis District of West Java Province. The Sentul male chickens were selected to achieve the average live weight of 1 $\mathrm{kg} / \mathrm{bird}$ at ten weeks of age, with grey (G) and blackspotted white (BSW) plumage color and pea-comb type. SenSi-1 Agrinak was released as an improved local meat-type chicken breed after six generations of selection (Iskandar, 2018).

The advantage of this breed is its relatively fast growth rate and potential for meat production. The potential of the Sentul chicken makes it possible to be bred as a popular local chicken farm commodity. The challenge that is often faced by the local chicken farms in the extensive system is the low disease resistance (Pagala \& Nafiu, 2012). The most prevalent diseases are caused by
Newcastle Disease (ND) virus and Salmonella enteritidis (S. enteritidis).

Newcastle Disease (ND) is a disease caused by a virus and is an important limiting factor in chicken farming. Newcastle Disease (ND) is endemic in Indonesia, such as chicken Tolaki, which is susceptible to ND disease (Pagala \& Nafiu, 2012). The period of ND virus is 4-6 days and the clinical symptoms are sudden death, drooping wings, weakness, loss of appetite, green diarrhea, and decreased egg production. Newcastle Disease (ND) virus can be spread through the air, feed, transport vehicles, wild birds, predators, clothing, and cage equipment (Pagala \& Nafiu, 2012).

Salmonella is a bacteria that is easy to grow and can adapt to various forms of environmental conditions. Contamination of Salmonella sp. may be found in chicken eggs. S. enteritidis is one of the zoonotic bacteria that can be transmitted through food (food-borne disease). Ulupi et al. (2013) found that 3.12\% of chicken eggs were positively contaminated with S. enteritidis in Bogor. The incidence of salmonellosis in humans is caused by con- 
suming chicken eggs containing the bacteria S. enteritidis (Velge et al., 2005). Ulupi et al. (2014) state that it is important to guarantee that the eggs of Kampung chicken are free from salmonellosis so that the eggs are safe for consumption.

Prevention of diseases is commonly done by vaccination. Vaccination is rarely conducted by producers with a very small amount of chicken. These conditions expose the small-scale farms of domestic chickens to diseases infection leading to the death of the chicken. This problem can be controlled by selecting chickens that resistance to those infectious agents. Genetic improvement has been accomplished mainly through the approach of molecular-genetic selection. The identification of SNP-based polymorphism is commonly used to determine the genetic variation of genes encoding certain traits (Gunawan et al., 2018). Many genes play roles in activating the resistance against diseases such as the Natural Resistance Associated Macrophage Proteins-1 (NRAMP-1) gene and Inducible Nitric Oxide Synthase (iNOS) gene.

The Natural Resistance Associated Macrophage Proteins-1 (NRAMP-1) gene and Inducible Nitric Oxide Synthase (iNOS) gene work in synergy with macrophage cells against pathogens. Macrophages and monocytes are part of an innate immune response and effectors and regulators of inflammation (Delgado et al., 2010). As an effector cell, monocyte equipped with chemokine receptors and pathogen recognition receptors. That can mediate the migration of monocytes from blood to tissues during infection. Monocytes can also differentiate into macrophages during inflammation. Migrations of monocytes to tissues and their further differentiation to macrophages are determined by the inflammatory milieu and pathogen-associated pattern of recognition receptors (Serbina et al., 2008). Monocytes will change shape and structure to become macrophage cells, which can immediately function as phagocytic cells. Phagocyte cells function to capture, swallow, kill, and destroy the antigens. Macrophages present these antigen particles to the surface as Antigen Presenting Cell (APC) (Wibawan \& Soedjono, 2013; Wils-Plotz \& Klasing, 2016). Subsequent reactions will induce the occurrence of specific immune responses mediated by helper $\mathrm{T}$ cells and B cells to produce specific antibodies (Abbas et al., 2017). The expression of the NRAMP-1 and iNOS genes in macrophage cells will facilitate the macrophages to engulf and kill pathogens or bacteria that successfully penetrate the tissue.

Several studies have shown that the NRAMP-1 and iNOS genes are associated with chicken resistance to $S$. enteritidis (Lamont et al., 2002; Malek \& Lamont, 2003; Tohidi et al., 2013). The study of He et al. (2013) reported that mutations at site g.24101991 A>T of NRAMP-1 gene were associated significantly with chicken resistance to S. enteritidis. The expression of the high NRAMP-1 and iNOS genes were found in liver and intestinal tissue (He et al. 2013; Sundaresan et al. 2005). Also, several studies have shown that there are genes controlling chicken resistance to diseases, such as the NRAMP-1 and iNOS genes (Tohidi et al., 2013). Muhsinin et al. (2016) reported that NRAMP-1 and iNOS genes were associated with immune traits in Indonesian local chicken. However, no study reported that NRAMP-1 and iNOS genes were found in selected local chicken. Therefore, the aim of this study to identify NRAMP-1 and iNOS genes polymorphisms and their associations against $S$. enteritidis and ND in SenSi-1 Agrinak chicken.

\section{MATERIALS AND METHODS}

The present study used SenSi-1 Agrinak chickens from Indonesian Research Institute for Animal Production (IRIAP). This research used 172 SenSi-1 Agrinak chickens of 24 weeks of age, consisting of 38 males and 134 females. The DNA was extracted from the blood samples by phenolchloroform method (Sambrook et al., 2001) at the Animal Molecular Genetics Laboratory, Faculty of Animal Science, IPB University and biological assays were conducted at the Division of Medical Microbiology, Faculty of Veterinary Medicine, IPB University, Indonesia.

\section{NRAMP-1 and iNOS Genotyping}

Identifications of NRAMP-1 and iNOS gene polymorphisms were performed in four stages: DNA extraction, DNA amplification, PCR-restriction fragment length polymorphism (PCR-RFLP) analysis, and DNA fragment visualization (Sambrook et al., 2001). The SNPs and primers for NRAMP1 and INOS were used according to Muhsinin et al. (2016). The primers for the NRAMP-1 gene (F: 5'-CAATGAGACGGTGTCTGTGG-3', R: 5'-CCCAGAAGAAATCTCCCTGC $\left.-3^{\prime}\right)$ and INOS gene (F: 5'-CCAAGGACTTACAGGTGTGG-3', R: 5'-CCAGGATGTTTGGGCTGTTG -3') were annealed at $60^{\circ} \mathrm{C}$ for $20 \mathrm{sec}$, respectively. The SNP at position $421 \mathrm{bp}$ (GAGCTIC) on chromosome 7 (exon 11) differentiated into different allelic transcripts of the NRAMP1 gene using the SacI enzyme. While the SNP at position 449 bp (AGICT) of chromosome 19 (intron 24) was differentiated into allelic transcripts of the INOS gene using the AluI enzyme. The Gen Bank accession numbers for the NRAMP1 and INOS genes are AY072001.1 and AF537190.1, respectively. The PCR-RFLP products were visualized using agarose gel electrophoresis for the NRAMP1 and INOS genes with concentrations of $2.0 \%$.

\section{Biological Assays}

Biological assays were used to analyze resistance factors in chickens, namely concentrations of immunoglobulin Y (IgY), Salmonella specific-antibodies (S. enteritidis), and ND antibodies titer (HI test). Immunoglobulin Y (IgY) concentrations were measured using indirect Enzyme-linked immunosorbent assays (ELISA), according to Mamutse et al. (2018). The analysis of Salmonella's specific-antibodies was carried out using the Clearance test. The clearance test is a method to measure the ability of antibodies to inhibit the growth of Salmonella bacteria. ND antibodies were measured using the haemagglutination inhibition to determine the antibodies titers again ND (Webster et al., 2002). 


\section{Data Analysis}

Genotype and allele frequencies observed and expected heterozygosities of the genotypes obtained via the PCR-RFLP method, Hardy-Weinberg equilibrium values, and polymorphic information contents (PICs) were calculated by POPGEN32 software. Association between the NRAMP-1 and iNOS genotypes with the immune properties of SenSi-1 Agrinak chickens was analyzed by analysis of variance (ANOVA) on the variables of immune properties analyzed using the GLM (General Linear Model) procedure with SAS 9.4 software (SAS Institute, Cary, NC, USA) and descriptive analysis with individual and categorized immune traits.

The association model used was as follows:

$Y_{\mathrm{ijk}}=\mu+G_{i}+S_{j}+C_{k}+\varepsilon_{i j k}$

where $Y_{i j k}$ was observations of immune traits, $\mu$ was population mean, $G_{i}$ was effect of the genotype, $S_{j}$ was effect of the sex, $\mathrm{C}_{\mathrm{k}}$ was effect of the category, and $\varepsilon_{\mathrm{ijk}}$ was residual error.

The immune parameters were further categorized into three groups, i.e., low, medium, and high titers. The criteria used for the titer ranges for the respective groups of IgY were $<5$ (low), $5 \leq x \leq 8$ (medium), and $>8$ $15 \mu \mathrm{g} / \mathrm{mL}$ (high), whereas the $S$. antibody titers (Log10) were $<4$ (low), $4 \leq x \leq 6$ (medium), and $>6 \mathrm{cfu} / \mathrm{mL}$ (high), and the HI antibody titers (Log2) were $<3$ (low), $3 \leq x \leq 5$ (medium), and $>5 \mathrm{cfu} / \mathrm{mL}$ (high).

\section{RESULTS}

NRAMP-1 exon 11 and iNOS intron 24 genes of SenSi-1 Agrinak chickens were successfully amplified to produce PCR product lengths of $421 \mathrm{bp}$ and $449 \mathrm{bp}$, respectively (Figure 1). The digestion of iNOS intron 24 fragments with AluI restriction enzymes resulted in 3 different restriction patterns (Figure 2). The first pattern was a gene fragment truncated by the AluI enzyme, indicated by two fragments at positions $310 \mathrm{bp}$ and $139 \mathrm{bp}$ designed the CC genotype. The second pattern had no $A l u \mathrm{I}$ restriction site resulting in one band at position 449 bp (TT genotype). The third pattern was a combination of all three fragments at positions 449, 310, and $139 \mathrm{bp}$ (TC heterozygous genotype). The RFLP analysis using the SacI restriction enzyme on the NRAMP-1 gene fragment in exon 11 resulted in 3 different fragments. Uncut Fragments by SacI enzymes (421 bp) were TT genotypes, truncated fragments ( $258 \mathrm{bp}$ and $163 \mathrm{bp}$ ) were CC genotypes, and combined fragments (421 bp, $258 \mathrm{bp}$, and 163 $\mathrm{bp}$ ) or heterozygotes were TC genotypes (Figure 2).

The immune response of SenSi-1 Agrinak chickens for NRAMP-1 and iNOS genes were shown in Table 1. The average titers of IgY, S. enteritidis antibody, and ND antibody were $7.89 \pm 3.96 \mu \mathrm{g} / \mathrm{mL}, 3.5 \times 10^{9} \pm 7.4 \times 10^{9} \mathrm{cfu} /$ $\mathrm{mL}$, and (Log 2) 3.11 \pm 2.19 , respectively (Table 1). The genotype and allele frequencies of NRAMP-1 and iNOS in SenSi-1 Agrinak chicken were shown in Table 2. The distributions of genotype and allele frequencies were (a)

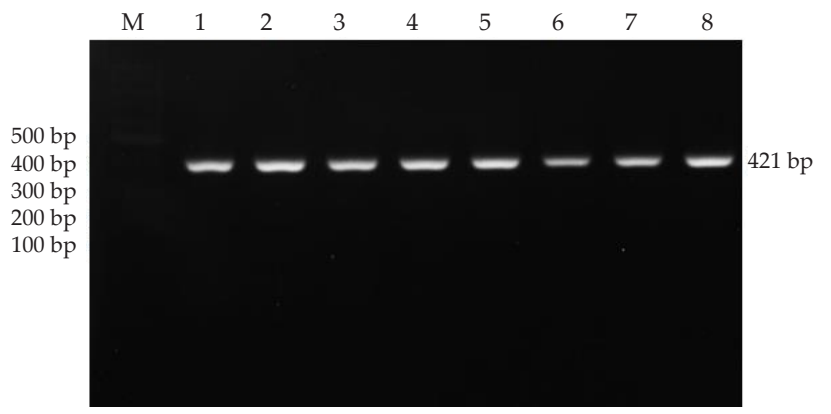

(b)

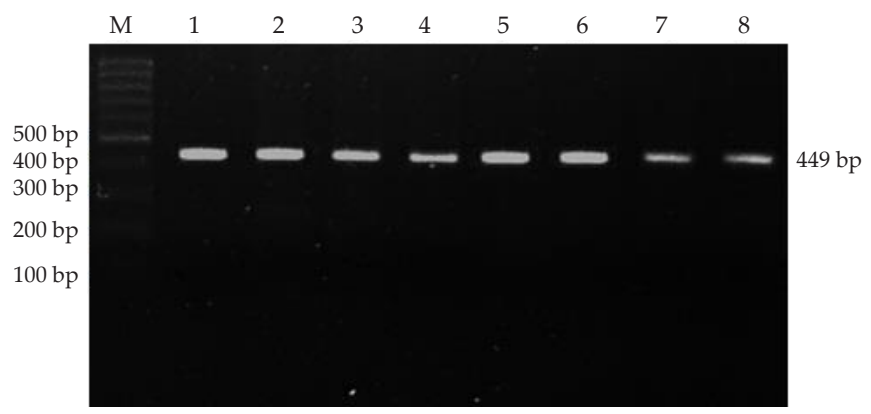

Figure 1. Amplification results of NRAMP1 gene exon 11 (a) and INOS gene intron 24 (b) in SenSi-1 Agrinak chicken. M= marker DNA 100 bp.

(a)

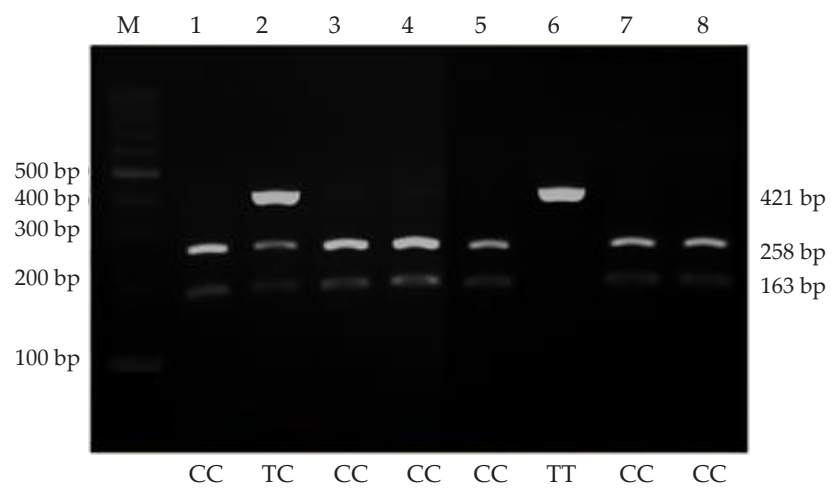

(b)

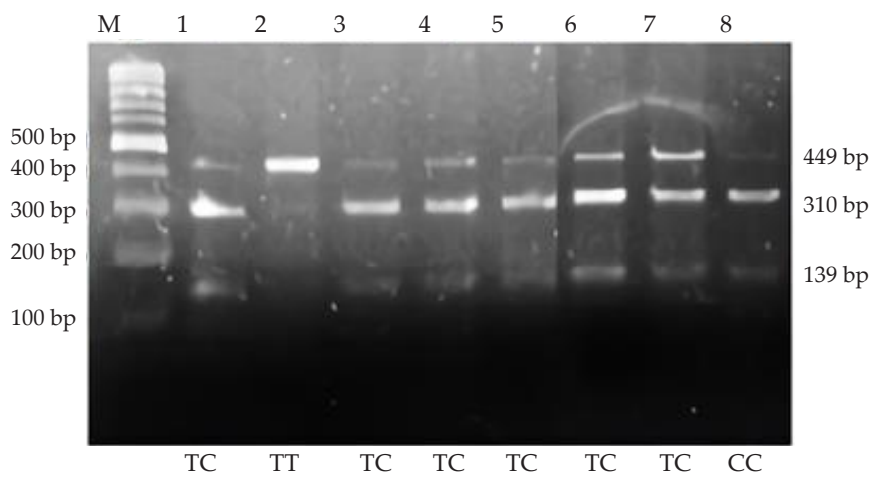

Figure 2. PCR-RFLP fragment results of NRAMP-1 gene exon 11 with restriction enzyme SacI (a) and INOS gene intron 24 with restriction enzyme AluI (b) in 2\% agarose gel M= marker DNA 100 bp (SenSi-1 Agrinak chicken). 
as follows: NRAMP-1 ( $\mathrm{TT}=0.023, \mathrm{TC}=0.238, \mathrm{CC}=0.738$, $\mathrm{T}=0.142$, and $\mathrm{C}=0.858)$ and $\mathrm{iNOS}(\mathrm{TT}=0.070, \mathrm{TC}=0.733$, $\mathrm{CC}=0.157, \mathrm{~T}=0.456$, and $\mathrm{C}=0.544)$.

Heterozygosity and polymorphic information contents of NRAMP-1 and iNOS in SenSi-1 Agrinak chicken are shown in Table 3 . The values of $\mathrm{Ho}, \mathrm{He}$, and PIC showed for the NRAMP-1 were $0.238,0.244$, and 0.460, respectively, and for the iNOS were $0.773,0.496$, and 0.956, respectively. The calculated (Chi-square) values for the NRAMP-1 gene (0.101) was significantly smaller than the critical value (3.84), different from iNOS gene (53.634) that was significantly higher than the critical value (3.84).

Genotypes and allele frequencys of NRAMP-1 I SacI and INOSIAluI of immune response categorized in SenSi-1 Agrinak chicken were shown in Tables 4, 5, 6, and 7. The CC genotypes of NRAMP-1 gene were higher in low and medium titers of IgY, different from TC genotype that was higher in high IgY titer (Table 4). The frequency of allele C of NRAMP-1 gene was higher than the frequencies of allele $\mathrm{T}$ in low, medium, and high titers of IgY $(0.824,0.914$, and 0.680) (Table 4). However, there was higher allele $\mathrm{T}(0.514)$ in low category of iNOS gene (Table 5). The CC genotype, TC genotype, and allele $\mathrm{C}$ frequencies were high in categorized immune responses of NRAMP-1 ISacI (Table 6) and iNOSIAluI (Table 7).
Association of the categorized immune responses of NRAMP-1ISacI and iNOSIAluI of categorized immune traits in SenSi-1 Agrinak chicken were shown in Table 8. The TC genotype of NRAMP-1ISacI was significantly associated with ND antibodies/ HI titers. The association of the iNOS showed significantly associated with S.enteritidis antibodies. The TT genotype of the iNOS with S.enteritidis antibodies showed significantly higher than TC and CC genotypes (Table 8).

\section{DISCUSSION}

NRAMP-1 and iNOS gene fragments were amplified at an annealing temperature of $60{ }^{\circ} \mathrm{C}$ for 20 seconds using the ESCO Thermocycler machine. This result is in accordance with the result reported by Muhsinin et al. (2016), but different from the result reported by Liu et al. (2016) and Ramasamy et al. (2011) at annealing temperature that has been carried out for the primers of NRAMP-1 exon 11 and iNOS intron 24 gene fragments, each at $64{ }^{\circ} \mathrm{C}$ for 90 seconds and $55^{\circ} \mathrm{C}$ for 1 minute.

The difference in annealing temperatures in both genes was caused by differences in the condition of the PCR machine and the mixture of PCR reagents. PCR optimization requires the right DNA polymerase. Harbison \& Nguyen (2017) stated that the annealing temperature ranged from $55-72{ }^{\circ} \mathrm{C}$. Besides that, the

Table 1. Descriptive statistics of immune traits of all investigated SenSi-1 Agrinak chickens

\begin{tabular}{lcccc}
\hline \multicolumn{1}{c}{ Variables } & Mean & St Dev & Minimum & Maximum \\
\hline IgY titer $(\mu \mathrm{g} / \mathrm{mL})$ & 7.89 & 3.96 & 0.96 & 14.95 \\
S. antibody titer $(\mathrm{cfu} / \mathrm{mL})$ & $3.5 \times 10^{9}$ & $7.4 \times 10^{9}$ & $4.4 \times 10^{3}$ & $3.7 \times 10^{10}$ \\
HI antibody titer $\left(\log _{2}\right)$ & 3.11 & 2.19 & 0 & 8 \\
\hline
\end{tabular}

Table 2. Genotype and allele frequencies of NRAMP-1 dan INOS in SenSi-1 Agrinak chickens

\begin{tabular}{|c|c|c|c|c|c|c|}
\hline \multirow{2}{*}{ Gene } & \multirow{2}{*}{$\mathrm{N}$} & \multicolumn{3}{|c|}{ Genotype frequency } & \multicolumn{2}{|c|}{ Allele frequency } \\
\hline & & TT & $\mathrm{TC}$ & $\mathrm{CC}$ & $\mathrm{T}$ & $\mathrm{C}$ \\
\hline NRAMP-1 & 172 & $0.023(4)$ & $0.238(41)$ & $0.738(127)$ & 0.142 & 0.858 \\
\hline INOS & 172 & $0.070(12)$ & $0.733(133)$ & $0.157(27)$ & 0.456 & 0.544 \\
\hline
\end{tabular}

Note: $\mathrm{N}=$ Total number of samples

Table 3. Heterozygosity and polymorphic information content of NRAMP-1 dan INOS in SenSi-1 Agrinak chickens

\begin{tabular}{ccccc}
\hline Gene & $\chi 2$ test & He & Ho & PIC \\
\hline NRAMP-1 & $0.101^{\text {ns }}$ & 0.244 & 0.238 & 0.216 \\
INOS & $53.634^{* *}$ & 0.496 & 0.773 & 0.371 \\
\hline
\end{tabular}

Note: $n s=$ not significant ${ }^{* *}=$ significant $(\mathrm{p}<0.01), \mathrm{x} 2$ count $<\mathrm{x} 2$ table, $0.05 ; 1=3.84 . \mathrm{He}=$ expected heterozygosity, Ho= observed heterozygosity, PIC $=$ polymorphism information content.

Table 4. Genotype and allele frequency of NRAMP-1 I SacI with IgY antibody

\begin{tabular}{|c|c|c|c|c|c|c|c|c|c|}
\hline \multirow{2}{*}{$\begin{array}{c}\text { Group of IgY } \\
\text { antibody NRAMP-1 }\end{array}$} & \multirow{2}{*}{$\begin{array}{l}\text { Total } \\
(\mathrm{N})\end{array}$} & \multicolumn{3}{|c|}{ Genotype } & \multicolumn{3}{|c|}{ Genotype frequency } & \multicolumn{2}{|c|}{ Allele frequency } \\
\hline & & TT & TC & $\mathrm{CC}$ & TT & TC & $\mathrm{CC}$ & $\mathrm{T}$ & $\mathrm{C}$ \\
\hline Low & 37 & 1 & 11 & 25 & 0.027 & 0.297 & 0.676 & 0.176 & 0.824 \\
\hline Medium & 93 & 2 & 12 & 79 & 0.022 & 0.129 & 0.849 & 0.086 & 0.914 \\
\hline High & 25 & 1 & 14 & 10 & 0.040 & 0.560 & 0.400 & 0.320 & 0.680 \\
\hline & 155 & 4 & 37 & 114 & 0.026 & 0.239 & 0.735 & 0.145 & 0.855 \\
\hline
\end{tabular}


Table 5. Genotype and allele frequency of INOS $\mid$ AluI with IgY antibody

\begin{tabular}{|c|c|c|c|c|c|c|c|c|c|}
\hline \multirow{2}{*}{$\begin{array}{l}\text { Group of IgY } \\
\text { antibody INOS }\end{array}$} & \multirow{2}{*}{$\begin{array}{l}\text { Total } \\
(\mathrm{N})\end{array}$} & \multicolumn{3}{|c|}{ Genotype } & \multicolumn{3}{|c|}{ Genotype frequency } & \multicolumn{2}{|c|}{ Allele frequency } \\
\hline & & TT & $\mathrm{TC}$ & $\mathrm{CC}$ & TT & TC & $\mathrm{CC}$ & $\mathrm{T}$ & $\mathrm{C}$ \\
\hline Low & 37 & 4 & 30 & 3 & 0.108 & 0.811 & 0.081 & 0.514 & 0.486 \\
\hline Medium & 93 & 2 & 73 & 18 & 0.022 & 0.785 & 0.194 & 0.414 & 0.586 \\
\hline High & 25 & 1 & 19 & 5 & 0.040 & 0.760 & 0.200 & 0.420 & 0.580 \\
\hline & 155 & 7 & 122 & 26 & 0.045 & 0.787 & 0.168 & 0.439 & 0.561 \\
\hline
\end{tabular}

Table 6. Genotype and allele frequency of NRAMP-1 I SacI with HI antibody

\begin{tabular}{|c|c|c|c|c|c|c|c|c|c|}
\hline \multirow{2}{*}{$\begin{array}{c}\text { Group of HI } \\
\text { antibody NRAMP-1 }\end{array}$} & \multirow{2}{*}{$\begin{array}{l}\text { Total } \\
(\mathrm{N})\end{array}$} & \multicolumn{3}{|c|}{ Genotype } & \multicolumn{3}{|c|}{ Genotype frequency } & \multicolumn{2}{|c|}{ Allele frequency } \\
\hline & & $\mathrm{TT}$ & TC & $\mathrm{CC}$ & TT & TC & $\mathrm{CC}$ & $\mathrm{T}$ & $\mathrm{C}$ \\
\hline Low & 74 & 2 & 6 & 66 & 0.027 & 0.081 & 0.892 & 0.068 & 0.932 \\
\hline Medium & 53 & 1 & 22 & 30 & 0.019 & 0.415 & 0.566 & 0.026 & 0.774 \\
\hline High & 26 & 1 & 8 & 17 & 0.038 & 0.308 & 0.654 & 0.192 & 0.808 \\
\hline & 153 & 4 & 36 & 113 & 0.026 & 0.235 & 0.739 & 0.144 & 0.856 \\
\hline
\end{tabular}

Table 7. Genotype and allele frequency of INOS|AluI with HI antibody

\begin{tabular}{|c|c|c|c|c|c|c|c|c|c|}
\hline \multirow{2}{*}{$\begin{array}{c}\text { Group of HI } \\
\text { antibody INOS }\end{array}$} & \multirow{2}{*}{$\begin{array}{l}\text { Total } \\
(\mathrm{N})\end{array}$} & \multicolumn{3}{|c|}{ Genotype } & \multicolumn{3}{|c|}{ Genotype frequency } & \multicolumn{2}{|c|}{ Allele frequency } \\
\hline & & TT & TC & CC & TT & TC & $\mathrm{CC}$ & $\mathrm{T}$ & $\mathrm{C}$ \\
\hline Low & 74 & 6 & 61 & 7 & 0.081 & 0.824 & 0.095 & 0.493 & 0.507 \\
\hline Medium & 53 & 2 & 38 & 14 & 0.019 & 0.717 & 0.264 & 0.377 & 0.623 \\
\hline High & 26 & 1 & 20 & 5 & 0.038 & 0.769 & 0.192 & 0.423 & 0.577 \\
\hline & 153 & 8 & 119 & 26 & 0.052 & 0.778 & 0.170 & 0.441 & 0.559 \\
\hline
\end{tabular}

Table 8. Antibody titers of IgY, S. enteritidis, and ND at difference genotypes of NRAMP-1 I SacI and INOS|AluI genes

\begin{tabular}{cccccccc}
\hline \multirow{2}{*}{ Gene } & \multirow{2}{*}{ Genotype } & \multicolumn{5}{c}{ Antibody } \\
\cline { 3 - 7 } & & $\mathrm{IgY}$ & $\mathrm{N}$ & S. enteritidis & $\mathrm{N}$ & $\mathrm{ND}$ & $\mathrm{N}$ \\
\hline \multirow{2}{*}{ NRAMP-1 } & TT & $10.507 \pm 1.934$ & $(4)$ & $7.600 \pm 0.741$ & $(5)$ & $4.250 \pm 0.973^{\mathrm{ab}}$ & $(4)$ \\
& TC & $9.666 \pm 0.636$ & $(37)$ & $8.083 \pm 0.276$ & $(36)$ & $5.055 \pm 0.324^{\mathrm{a}}$ & $(36)$ \\
& CC & $7.212 \pm 0.362$ & $(114)$ & $7.500 \pm 0.153$ & $(116)$ & $2.606 \pm 0.183^{\mathrm{b}}$ & $(113)$ \\
\multirow{2}{*}{ INOS } & TT & $7.570 \pm 1.500$ & $(7)$ & $10.000 \pm 0.535^{\mathrm{a}}$ & $(7)$ & $3.125 \pm 0.779$ & $(8)$ \\
& TC & $8.230 \pm 0.359$ & $(122)$ & $7.842 \pm 0.126^{\mathrm{b}}$ & $(127)$ & $3.332 \pm 0.202$ & $(119)$ \\
& CC & $6.339 \pm 0.778$ & $(26)$ & $5.782 \pm 0.295^{\mathrm{c}}$ & $(23)$ & $2.769 \pm 0.432$ & $(26)$ \\
\hline
\end{tabular}

Note: $\mathrm{N}=$ total individual; means in the same column with different superscripts differ significantly $(\mathrm{p}<0.05)$.

optimal temperature of annealing was influenced by the concentration of $\mathrm{MgCl}_{2}$ (Viljoen et al., 2005). Incorrect annealing temperature can cause no primary attachment. The timing of the annealing process is related to the primary length. The primary length of $18-22$ bases is enough with 30 seconds, while for primary lengths more than 22 bases, annealing time of 60 seconds is required (McPherson \& Moller, 2006).

Research results of Muhsinin et al. (2016) and Tohidi et al. (2013) showed that the genotype of the NRAMP-1 gene CC had a high frequency and that the TT genotype was found to be low in both chickens. In the iNOS intron 24 gene fragment, it was found high TC genotype frequencies. Different results were reported in Barnevelder and Broiler chickens (Kramer et al., 2003) and in Indonesian local chickens (Muhsinin et al., 2016).

The results of this study indicate that the NRAMP1 S SacI exon 11 and iNOSIAluI intron 24 in SenSi-1 Agrinak chickens are polymorphic because there are three types of genotypes found in each of these gene fragments and allele frequencies obtained are more than 0.01 (Nei \& Kumar, 2000; Togashi \& Lin, 2010; Allendorf et al., 2013). The high frequency of C allele in SenSi-1 Agrinak chicken populations was thought to be due to breeding selection and management. Selection made by breeders is to maintain chickens that have a $C$ allele compared to chickens that have $\mathrm{T}$ alleles. According to Noor (2010), the factors that influence gene frequency are selection, mutation, population mixing, internal crossing, outer crossing, and genetic drift.

The value of heterozygosity is the average percentage of heterozygous loci of each individual or the average percentage of heterozygous individuals in the population (Nei \& Kumar, 2000). The observed heterozygosity values (Ho) in SenSi-1 Agrinak chicken analyzed was 0.238 on NRAMP-1ISacI and 0.773 on iNOS $\mid A l u \mathrm{I}$. The value of expected heterozygosity $(\mathrm{He})$ in SenSi-1 Agrinak chickens analyzed was 0.244 on 
NRAMP-1ISacI and 0.496 on iNOSIAluI. At the NRAMP-1 I SacI locus exon 11 showed a lower Ho value than iNOSIAluI. This result can be used as an indication of the degree of endogamy (inbreeding) as a result of an intensive selection process (Machado et al., 2003; Ryan \& Ray, 2014). A large difference between the values of Ho and He can be used as an indicator of the presence of genotype imbalances in the population analyzed (Tambasco et al., 2003; Harbison \& Nguyen, 2017).

The PIC value is an ideal index to measure the polymorphism of allele fragments. According to Botstein et al. (1980), if the PIC value $\geq 0.50$ indicates a very informative locus, the PIC value $0.25<$ PIC $<0.50$ indicates a fairly informative locus, and the PIC value $\leq$ 0.25 indicates the locus has a low informative category. Based on the statement, the value of the NRAMP-1 I SacI gene exon 11 belongs to the medium category. The iNOSIAluI gene intron 24, the PIC value, is in a low category that is very informative.

The results of the clearance test showed that the genotype of the NRAMP-1 and iNOS genes could kill $S$. enteritidis bacteria higher than TC and TT genotypes. Bacterial death on clearance tests was caused by phagocytic processes mediated by heterophil cells and antibodies in serum blood formed by lymphocyte cells (Cherayil, 2011; Pecoraro et al., 2017). The results of this study are similar to those reported by Tohidi et al. (2012) that CC genotypes in Malaysia local chickens were more resistant to $S$. enteritidis bacterial infections.

NRAMP-1 triggers a non-immune response that works on the host cells and expressed on phagocytic cells (Cellier, 2017). NRAMP-1 functions to modulate cytocidal proteins that are toxic to the cells, such as bacterial cells and transmembrane conserving. In addition to macrophages, NRAMP-1 can form on lymph cells and the liver because it easily recognizes lipopolysaccharides (LPS) from Salmonella so that the host becomes resistant to Salmonella (Yuniwarti et al., 2013; He et al., 2013; Hu et al., 2015). The results of IgAMP on NRAMP1 both homozygous and heterozygous show high IgY. In the HI test, NRAMP1 did not associate with the ND virus. It happens because the HI test detects anti-ND antibodies, which are specific immunity, which is only formed if there is an induction of ND antigens both due to natural infection and vaccination.

iNOS can inhibit bacterial metabolism in Clearance test. This result is proven by the ability to neutralize the bacteria close to $100 \%$. HI testing shows that iNOS is positively associated. This result is in accordance with its function because iNOS is an intracellular enzyme that has a function of oxidizing so that it will inhibit viral replication. Susceptibility to antibiotics for antimicrobial activity against $S$. enteritidis and Enterococcus casseliflavus, and ability to adhere to ileal cells of chicken (Hamida et al., 2015; Guo et al., 2016; Li et al., 2017).

NRAMP-1 and iNOS genes are included in the natural immune system that is genetic. Several studies have revealed the association between NRAMP-1 and iNOS genes against disease resistance, including the associations with tuberculosis in humans (Medapati et al., 2017; Mahmud et al., 2017), salmonella disease in mice (Bauler et al., 2017; Reventun et al., 2017), tuberculosis in cattle (Pereira-Suárez et al., 2006; Delgado et al., 2010), the nature of immunity in pigs (Dai et al., 2017; Yan et al., 2017), Rhodococcus equi pneumonia in horses (Halbert et al., 2006), salmonella and viruses in goats and sheep (Lantier et al., 2012; Dincel \& Kul, 2015;), and S. enteritidis in chickens (Kramer et al., 2003; Tohidi et al., 2013; Jin et al., 2015; Psifidi et al., 2016; Sun et al., 2017).

\section{CONCLUSION}

NRAMP-1|SacI exon 11 and iNOS|AluI intron 24 in SenSi-1 Agrinak chicken were polymorphic. TC genotype of NRAMP-1 gene was associated with ND antibody, and the TT genotype of iNOS associated with S. enteritidis antibodies. This study demonstrated that SNP of NRAMP-1 and iNOS might be used as potential candidate markers for the selection of high immune traits in local chicken.

\section{CONFLICT OF INTEREST}

Cece Sumantri and Asep Gunawan serve as editor of the Tropical Animal Science Journal, but have no role in the decision to publish this article. The authors also declare that there is no conflict of interest with any financial, personal, or other relationships with other people or organizations related to the material discussed in the manuscript.

\section{ACKNOWLEDGEMENT}

We would like to give our respect to the Minister of Agriculture, Indonesia, for the research assistance provided through the KP4S 2018 (740/PL/H.1/07/2018.K) and Word Class Research, with contract number: 121/ SPH/LT/DPRM/2019.

\section{REFERENCES}

Abbas, A.K., A.H. Lichtman, \& S. Pilai. 2017. Molecular and cellular immunology. 9th ed. Elsevier, Philadelphia.

Allendorf, F.W., G. Luikar, \& S.N. Aitken. 2013. Conservation and the genetics of population. 2nd ed. Wiley-Blackwell, Oxford.

Bauler, T.J., T. Starr, T.A. Nagy, S. Sridhar, D. Scott, C.W. Winkler, O. Steele-Mortimer, C.S. Detweiler, \& K.E. Peterson. 2017. Salmonella meningitis associated with monocyte infiltration in mice. Am. J. Pathol. 187: 187-199. https://doi.org/10.1016/j.ajpath.2016.09.002

Botstein, D, R.L. White, M. Skolnick, \& R.W. Davis. 1980. Construction of genetic linkage map in human using restriction fragmen length polymorphisms. Amer. J. Hum. Genet. 32: 314-331.

Cellier, M.F.M. 2017. Developmental control of NRAMP-1 (SLC11A1) expression in professional phagocytes. Biology 6: 28. https://doi.org/10.3390/biology6020028

Cherayil, B.J. 2011. The role of iron in the immune response to bacterial infection. Immunol. Res. 50: 1-9. https://doi. org/10.1007/s12026-010-8199-1

Dai, C.H., J.Y. Wu, C.X. Zhao, L.H. Yu, W.B. Bao, \& S.L. Wu. 2017. NRAMP-1 gene expression in different tissues of meishan piglets from newborn to weaning. Genet. Mol. Res. 16: 1-10. https://doi.org/10.4238/gmr16019288

Delgado, F., C. Estrada-Chávez, M. Romano, F. Paolicchi, F. Blanco-Viera, F. Capellino, G. Chavez-Gris, \& A.L. 
Pereira-Suárez. 2010. Expression of NRAMP-1 and iNOS in mycobacterium avium subsp. paratuberculosis naturally infected cattle. Comp. Immunol. Microbiol. Infect. Dis. 33: 389-400. https://doi.org/10.1016/j.cimid.2009.03.001

Dincel, G.C. \& O. Kul. 2015. eNOS and iNOS trigger apoptosis in the brains of sheep and goats naturally infected with the border disease virus. Histol. Histopathol. 30: 1233-1242.

Geissmann, F., M.G. Manz, S. Jung, M.H. Sieweke, M. Merad, \& K. Ley. 2010. Development of monocytes, macrophages and dendritic cells. Science 327: 656-661. https://doi. org/10.1126/science.1178331

Gunawan, A., D. Anggrela, K. Listyarini, M.A. Abuzahra, Jakaria, M. Yamin, I. Inounu, \& C. Sumantri. 2018. Identification of Single Nucleotide Polymorphism and Pathway Analysis of Apolipoprotein A5 (APOA5) Related to Fatty Acid Traits in Indonesian Sheep. Trop. Anim. Sci. J. 41:165-173. https://doi.org/10.5398/tasj.2018.41.3.165

Guo, R., S. Geng, H. Jiao, Z. Pan, X. Chen, \& X. Jiao. 2016. Evaluation of protective efficacy of a novel inactivated Salmonella pullorum ghost vaccine against virulent challenge in chickens. Vet. Immunol. Immunopathol. 173: 2733. https://doi.org/10.1016/j.vetimm.2016.03.015

Halbert, N.D., N.D. Cohen, N.M. Slovis, J. Faircloth, \& R.J. Martens. 2006. Variations in equid SLC11A1 (NRAMP1) genes and associations with rhodococcus equi pneumonia in horses. J. Vet. Intern. Med. 20: 974-979. https://doi. org/10.1111/j.1939-1676.2006.tb01814.x

Hamida, F., K.G. Wiryawan, \& A. Meryandini. 2015. Selection of lactic acid bacteria as probiotic candidate for chicken. Med. Pet. 38:138-144. https://doi.org/10.5398/ medpet.2015.38.2.138

Harbison, A.M. \& J.N.T. Nguyen. 2017. PCR: Identifcation of genetic polymorphisms. Methods Mol. Biol. 1606: 193-203. https://doi.org/10.1007/978-1-4939-6990-6_13

He, X.M., M.X. Fang, Z.T. Zhang, Y.S. Hu, X.Z. Jia, D.L. He, S.D. Liang, Q.H. Nie, \& X.Q. Zhang. 2013. Characterization of chicken natural resistance-associated macrophage proteinencoding genes (Nramp1 and Nramp2) and association with salmonellosis resistance. Genet. Mol. Res. 12: 618-630. https://doi.org/10.4238/2013.January.30.5

Hu, Y., Y.J. Shan, C.H. Zhu, W.T. Song, W.J. Xu, W.Q. Zhu, S.J. Zhang, \& H.F. Li. 2015. Up-regulation of NRAMP1 mRNA confirms its role in enhanced host immunity in post-artificial infections of Salmonella enteritidis in chicks. Br. Poult. Sci. 56: 408-415. https://doi.org/10.1080/00071668 .2015.1052371

Iskandar, S. 2018. Phenotypic characterization and distributin of SenSi-1 Agrinak chicken. Wartazoa. 28:051-060. https:// doi.org/10.14334/wartazoa.v28i2.1673

Jin, Y.C., P. Wei, S. Cui, \& L. Huang. 2015. The relationship between the three-dimensional (3D) structures of $\mathrm{BF}$ molecules and MHC-related Marek's disease resistance in chickens. Scand. J. Immunol. 81: 325-327. https://doi. org/10.1111/sji.12278

Kramer, J., M. Malek, \& S.J. Lamont. 2003. Association of twelve candidate gene polymorphisms and response to challenge with Salmonella enteritidis in poultry. Anim. Genet. 34: 339-348. https://doi.org/10.1046/j.1365-2052.2003.01027.x

Lamont, S.J., W. Liu, \& M. Kaiser. 2002. Natural resistance associated macrophage protein 1 gene polymorphisms and response to vaccine against or challenge with Salmonella enteritidis in young chicks. Poult. Sci. 82: 259-266. https:// doi.org/10.1093/ps/82.2.259

Lantier, I., C.R. Moreno, P. Berthon, G. Sallé, F. Pitel, L. Schibler, A.V. Gautier-Bouchardon, R. Boivin, J.L. Weisbecker, \& D. François. 2012. Quantitative trait loci for resistance to infection in sheep using a live Salmonella abortusovis vaccine. Anim. Genet. 43: 632-635. https://doi. org/10.1111/j.1365-2052.2011.02291.x
Li, P., H. Wang, X. Zhao, Z. Gou, R. Liu, Y. Song, Q. Li, M. Zheng, H. Cui, N. Everaert, G. Zhao, \& J. Wen. 2017. Allelic variation in TLR4 is linked to resistance to Salmonella enteritidis infection in chickens. Poult. Sci. 96: 2040-2048. https://doi.org/10.3382/ps/pex010

Liu, L., X.W. Zhao, Y.M. Song, Q.H. Li, P. Li, R.R. Liu, M.Q. Zheng, J. Wen, \& G.P. Zhao. 2016. Difference in resistance to Salmonella enteritidis infection among allelic variants of TLR4 $(903,1832)$ in SPF chickens. J. Appl. Genet. 57: 389396. https://doi.org/10.1007/s13353-015-0324-3

Machado, M.A., I. Schuster, M.L. Martinez, \& A.L. Campos. 2003. Genetic diversity of four cattle breed using microsatellite markers. Rev. Bras. De Zool. 32: 93-98. https://doi. org/10.1590/S1516-35982003000100012

Mahmud, H.A., H. Seo, S. Kim, M.I. Islam, K.W. Nam, H.D. Cho, \& H.Y. Song. 2017. Thymoquinone (TQ) inhibits the replication of intracellular Mycobacterium tuberculosis in macrophages and modulates nitric oxide production. BMC Complement Altern. Med. 17: 279-287. https://doi. org/10.1186/s12906-017-1786-0

Malek, M. \& S.J. Lamont. 2003. Association of INOS, TRAIL, TGF-b2, TGF-b3, and IgL genes with response to Salmonella enteritidis in poultry. Genet. Sel. Evol. 1: 99111. https://doi.org/10.1186/1297-9686-35-S1-S99

Mamutse, J., A. Gunawan, C. Sumantri, S. Murtini, \& T. Sartika. 2018. Association of the Toll-Like Receptor 4 (TLR4) and Myxovirus (MX) genes with resistance to Salmonella and Newcastle Disease in selected sentul chickens. Int. J. Poult. Sci. 17: 591-599. https://doi.org/10.3923/ijps.2018.591.599

McPherson, M.J. \& S.G. Moller. 2006. PCR. 2nd ed. Taylor \& Francis Group, New York. https://doi. org/10.4324/9780203002674

Medapati, R.V., S. Suvvari, S. Godi, \& P. Gangisetti. 2017. NRAMP1 and VDR gene polymorphisms in susceptibility to pulmonary tuberculosis among Andhra Pradesh population in India: a case-control study. BMC Pulm. Med. 17: 89-95. https://doi.org/10.1186/s12890-017-0431-5

Muhsinin, M., N. Ulupi, A. Gunawan, I.W.T. Wibawan, \& C. Sumantri. 2016. Association of NRAMP1 polymorphisms with immune traits in Indonesian native chickens. Int. J. Poult. Sci. 15: 401-406. https://doi.org/10.3923/ ijps.2016.401.406

Nei, M. \& S. Kumar. 2000. Molecular Evolution and Phylogenetics. Oxford University Press, New York.

Noor, R.R. 2010. Genetika Ternak. Penebar Swadaya, Jakarta.

Pagala, M.A. \& L.O. Nafiu. 2012. Identifikasi molekuler sifat anti viral ayam Tolaki melalui deteksi gen Mx sebagai marka genetik. Agriplus. 23:139-144.

Pecoraro, H.L., B. Thompson, \& G.E. Duhamel. 2017. Histopathology case definition of naturally acquired Salmonella enterica serovar Dublin infection in young Holstein cattle in the northeastern United States. J. Vet. Diagn. Invest. 29: 860-864. https://doi. org/10.1177/1040638717712757

Pereira-Suárez, A.L., C. Estrada-Chávez, C. Arriaga-Díaz, P. Espinosa-Cueto, \& R. Mancilla. 2006. Coexpression of NRAMP1, iNOS, and nitrotyrosine in bovine tuberculosis. Vet. Pathol. 43: 709-717. https://doi.org/10.1354/vp.43-5-709

Psifidi, A., G. Banos, O. Matika, T.T. Desta, J. Bettridge, D.A. Hume, T. Dessie, R. Christley, P. Wigley, O. Hanotte, \& P. Kaiser. 2016. Genome-wide association studies of immune, disease and production traits in indigenous chicken ecotypes. Genet. Sel. Evol. 48: 74-90. https://doi. org/10.1186/s12711-016-0252-7

Ramasamy, K.T., M.R. Reddy, \& S. Murugesan. 2011. Toll-like receptor mRNA expression, INOS gene polymorphism and serum nitric oxide levels in indigenous chickens. Vet. Res. Commun. 35: 321-327. https://doi.org/10.1007/ s11259-011-9472-z 
Reventun, P., M. Alique, I. Cuadrado, S. Marquez, R. Toro, C. Zaragoza, \& M. Saura. 2017. iNOS-Derived nitric oxide induces integrin-linked kinase endocytic lysosome-mediated degradation in the vascular endothelium. Arterioscler Thromb Vasc. Biol. 37: 1272-1281. https://doi.org/10.1161/ ATVBAHA.117.309560

Ryan, K.J. \& C.G. Ray. 2014. Sherris Medical Microbiology. 6th ed. McGraw Hill, New York.

Sambrook, J., E.F. Fritsch, \& T. Maniatis. 2001. Molecular Cloning: A Laboratory Manual. Cold Spring Harbor Laboratory Press. Cold Spring Harbor, NY.

Serbina, N.V., T. Jia, T.M. Hohl, \& E.G. Pamer. 2008. MonocyteMediated Defense against Microbial Pathogens. Annu. Rev. Immunol. 26:421. [PubMed: 18303997]. https://doi. org/10.1146/annurev.immunol.26.021607.090326

Sun, X., S. Li, Y. He, H. Zhao, Y. Wang, X. Zeng, \& M. Xing. 2017. Arsenic-induced testicular toxicity in Gallus gallus: Expressions of inflammatory cytokines and heat shock proteins. Poult. Sci. 96:3399-3406. https://doi.org/10.3382/ ps/pex073

Sundaresan, N.R., K.A. Ahmed, V.K. Saxena, K.V. Sastry, M. Saxena, A.B. Pramod, M. Nath, K.B. Singh, T.J. Rasool, A.K. DevRoy, \& R.V. Singh. 2005. Differential expression of inducible nitric oxide synthase and cytokine mRNA in chicken lines divergent for cutaneous hypersensitivity response. Vet. Immunol. Immunopathol. 108: 373-385. https://doi.org/10.1016/j.vetimm.2005.06.011

Tambasco, D.D., C.C.P. Paz, M. Tambasco-Studart, A.P. Pereira, M.M. Alencar, A.R. Freitas, L.L. Coutinho, I.U. Packer, \& C.A. Regitano. 2003. Candidate genes for growth traits in beef cattle crosses Bos taurus $\mathrm{x}$ Bos indicus. J. Anim. Breed Genet. 120: 51-56. https://doi. org/10.1046/j.1439-0388.2003.00371.x

Togashi, K. \& C.Y. Lin. 2010. Theoretical efficiency of multiple-trait quantitative trait loci-assisted selection. J. Anim. Breed Genet.127: 53-63. https://doi. org/10.1111/j.1439-0388.2009.00817.x

Tohidi, R., I. Idris, J.M. Panandam, \& M.H. Bejo. 2012. The effects of polymorphisms in IL-2, IFN- $\gamma$, TGF- $\beta 2$, IgL, TLR-4, MD-2, and iNOS genes on resistance to Salmonella enteritidis in indigenous chickens. Avian Pathol. 41: 605-612. https://doi.org/10.1080/03079457.2012.739680
Tohidi, R., I.B. Idris, J.M. Panandam, \& M.H. Bejo. 2013. The effects of polymorphisms in 7 candidate genes on resistance to Salmonella enteritidis in native chickens. Poult. Sci. 92: 900-909. https://doi.org/10.3382/ps.2012-02797

Ulupi, N., Muladno, C. Sumantri, \& I.W.T. Wibawan. 2013. Association of TLR4 gene genotype and resistance against Salmonella enteritidis natural infection in kampung chicken. Int. J. Poult. Sci. 12: 445-450. https://doi.org/10.3923/ ijps.2013.445.450

Ulupi, N., Muladno, C. Sumantri, \& I.W.T. Wibawan. 2014. Study of kampung chicken resistance against Salmonella enteritidis using TLR4 gene as marker. Int. J. Poult. Sci. 13: 467-472. https://doi.org/10.3923/ijps.2014.467.472

Ulupi, N., Muladno, C. Sumantri, \& I.W.T. Wibawan. 2014. Identifikasi keragaman gen Toll-Like Receptor-4 ayam lokal dengan polymerase chain reaction- restriction fragment lenght polymorphism. Jurnal Veterin. 15: 345-352.

Velge, P., A. Cloeckaert, \& P. Barrow. 2005. Emergence of Salmonella epidemics : the problems related to Salmonella enterica serotype enteritidis and multiple antibiotic resistance in other major serotypes. Vet. Res. 36:267-288. https:// doi.org/10.1051/vetres:2005005

Viljoen, G.J., L.H. Nel, \& J.R. Crowther. 2005. Molecular Diagnosis PCR Handbook. Springer, Netherlands.

Webster, R., N. Cox, \& K. Stohr. 2002. WHO Manual on Animal Influenza Diagnosis and Surveillance.

Wibawan, I.W.T. \& R.D. Soedjono. 2013. Intisari Imunologi Medis. Fakultas Kedokteran Hewan Institut Pertanian Bogor, Bogor

Wils-Plotz, E.L. \& K.C. Klasing. 2016. Effects of immunomodulatory nutrients on growth performance and immunerelated gene expression in layer chicks challenged with lipopolysaccharide. Poult. Sci. 96: 548-555. https://doi. org/10.3382/ps/pew376

Yan, M., M. Hou, J. Liu, S. Zhang, B. Liu, X. Wu, \& G. Liu. 2017. Regulation of INOS-Derived ROS generation by HSP90 and Cav-1 in porcine reproductive and respiratory syndrome virus-infected swine lung injury. Inflammation 40: 1236-1244. https://doi.org/10.1007/s10753-017-0566-9

Yuniwarti, E.Y.W., W. Asmara, W.T. Artama, \& C.R. Tabbu. 2013. Virgin coconut oil meningkatkan aktivitas fagositosis makrofag ayam pedaging pasca vaksinasi flu burung. J. Vet. 14: 190-196. 